\section{Sweet cassava cultivars with yellow or cream root pulp developed by participatory breeding}

\author{
Eduardo Alano Vieira ${ }^{1^{*}}$, Josefino de Freitas Fialho ${ }^{1}$, Laercio de \\ Julio², Luiz Joaquim Castelo Branco Carvalho ${ }^{3}$, João Luis Dalla \\ Corte $^{1}$, Maria Madalena Rinaldi ${ }^{1}$, Charles Martins de Oliveira ${ }^{1}$, \\ Francisco Duarte Fernandes ${ }^{1}$ and José de Ribamar Nazareno \\ dos Anjos ${ }^{1}$
}

\begin{abstract}
The sweet cassava cultivars BRS 396, BRS 397, BRS 398 and BRS 399, were selected through 27 participatory tests conducted at Distrito Federal, Brazil. Their agronomic performance and their high level of acceptance among producers qualify them as a new crop option for cultivation in the region.
\end{abstract}

Keywords: Manihot esculenta Crantz, participatory plant breeding, sensory qualities.

\section{INTRODUCTION}

Cassava production at the Federal District (DF) is concentrated in small farms. There, the use of family labor is common, and roots with cream or yellow pulps for cooking are the most common crops. The crop occupies a cultivated area of 1,600 ha annually, with an average yield of $16 \mathrm{t} \mathrm{ha}^{-1}$. Since sweet cassava producers in the region already use sophisticated production technologies, one way to increase their productivity substantially would be the adoption of more productive cultivars.

Embrapa's sweet cassava breeding program is focused on the development of specific cultivars for the production of tuberous roots for human consumption (cooked, fried, chips, precooked, pasta etc). The following properties are desirable in these crops: level of hydrocyanic acid (HCN) in fresh roots less than $100 \mathrm{mg}$ $\mathrm{kg}^{-1}$, high yields, pleasant sensory qualities (softness and plasticity after cooking, non-sticky mass, aroma and pleasant appearance); good culinary properties (low fiber content, short cooking time and homogeneous mass after cooking); desirable architecture for cultivation (fewer and higher branches); resistance to pests and diseases; yellow or cream coloration of the root pulp; among other characteristics (Vieira et al. 2011a, Vieira et al. 2011b, Carvalho et al. 2011). Besides all these desirable qualities, the crop needs to be be well accepted by both producers and consumers of cassava in the Federal District region.

To meet the demand for sweet cassava, Embrapa offers regional producers the cultivars BRS 396, BRS 397, BRS 398 and BRS 399, which are well adapted to the conditions of the Federal District. As has been done for other annual crops (Chiorato et al. 2018, Franco et al. 2018).
Crop Breeding and Applied Biotechnology 18: 450-454, 2018 Brazilian Society of Plant Breeding. Printed in Brazil http://dx.doi.org/10.1590/1984$70332018 v 18 n 4 c 67$
$*$ *Corresponding author:
E-mail: eduardo.alano@embrapa.br

Received: 11 June 2018 Accepted: 07 August 2018

${ }^{1}$ Embrapa Cerrados, BR 020, km 18, 73.310970, Planaltina, DF, Brazil 2 EMATER-DF escritório Embrapa Cerrados, BR 020, km 18, 73.310-970, Planaltina, DF, Brazil

${ }^{3}$ Embrapa Recursos Genéticos e Biotecnologia, Parque Estação Biológica, PqEB, Av. W5 Norte, 70.770-917, Brasília, DF, Brazil 


\section{BREEDING METHOD APPLIED}

The sweet cassava cultivars BRS 396 and BRS 397 were selected from a segregating population generated through the cross between the cassava varieties BRS Moura and IAC 576-70, preserved at the Cerrados Germplasm Regional Bank, codes BGMC 1289 and BGMC 753. Cultivars BRS 398 and BRS 399, in contrast, were selected from an open pollinated population of access BGMC 1218, of which the male parent is not known.

The crops were planted and harvested in November of consecutive years following the recommendations for cassava cultivation in the Brazilian Cerrado (Fialho et al. 2013, Fialho and Vieira 2013).

The cassava plants obtained from seeds have a pivotal type root system. The following selection criteria were adopted in the first selection cycle (2007/2008): i) yellow or cream root pulp; ii) architecture (plants with first branching high up); and iii) bacterial blight resistance. The clones selected in this harvest were planted in the field in rows with 5 plants each, a space of $1.20 \mathrm{~m}$ between plants and $0.80 \mathrm{~m}$ between rows and were subjected to the second selection cycle.

During the second selection cycle (2008/2009), cassava plants began to be propagated by means of stem cuttings and to display a tuberosal root system, typical of commercial crops. The criteria for selecting them during this cycle were as follows: i) architecture (plants with first branching high up); ii) resistance to cassava bacterial blight; iii) root productivity; iv) root cooking time less than 30 minutes; v) uniformity of the root (more than $80 \%$ of the roots between 20 and $45 \mathrm{~cm}$ in length and diameter greater than $50 \mathrm{~mm}$ ); and (vi) HCN content in the roots less than $100 \mathrm{mg} \mathrm{kg}^{-1}$. The clones selected in this harvest were planted in blocks of 5 rows with 5 plants spaced 0.80 between plants and 1.20 between rows and were subjected to the third selection cycle.

The third selection cycle (2009/2010) was also conducted at Embrapa Cerrados. The same criteria employed for the second cycle were used for selection. The clones selected in the third cycle were subjected to the Differentiation, Homogeneity and Stability tests of the cassava cultivar (Manihot esculenta Crantz) of the Ministério da Agricultura, Pecuária e Abastecimento (MAPA). The experimental design was a randomized complete block design with three replications. Each plot was composed of 4 rows of 10 plants with spacing of $0.80 \mathrm{~m}$ between plants and $1.20 \mathrm{~m}$ between rows. Sixteen central plants per plot were evaluated. In this step, in addition to the parameters evaluated in the last two selection cycles, in each plot of the experiments, the hydrocyanic acid (HCN) content of the roots was also estimated in $\mathrm{mg} \mathrm{kg}^{-1}$ using the qualitative method described by Williams and Edwards (1980), from five roots chosen at random from each plot.

\section{PARTICIPATIVE EVALUATION}

The method of participatory selection of varieties was used to evaluate the cassava cultivars. This process is characterized by effective participation of the farmers, researchers and extension personnel in the clonal validation process (Fialho and Vieira 2011). In the end of the process, agricultural data and the degree to which the producers accepted the clones, which is an indication of the probability that they will plant them in the future, were obtained. This scenario is expected since the farmers were encouraged to classify clones according to their preferences. Therefore, the clones that were more often rated on the top positions by the producers are the ones that are most likely to be used by them in the future.

The cultivars BRS 396, BRS 397, BRS 398 and BRS 399 were selected after 27 participatory tests (Figure 1), which involved the evaluation of 13 sweet cassava

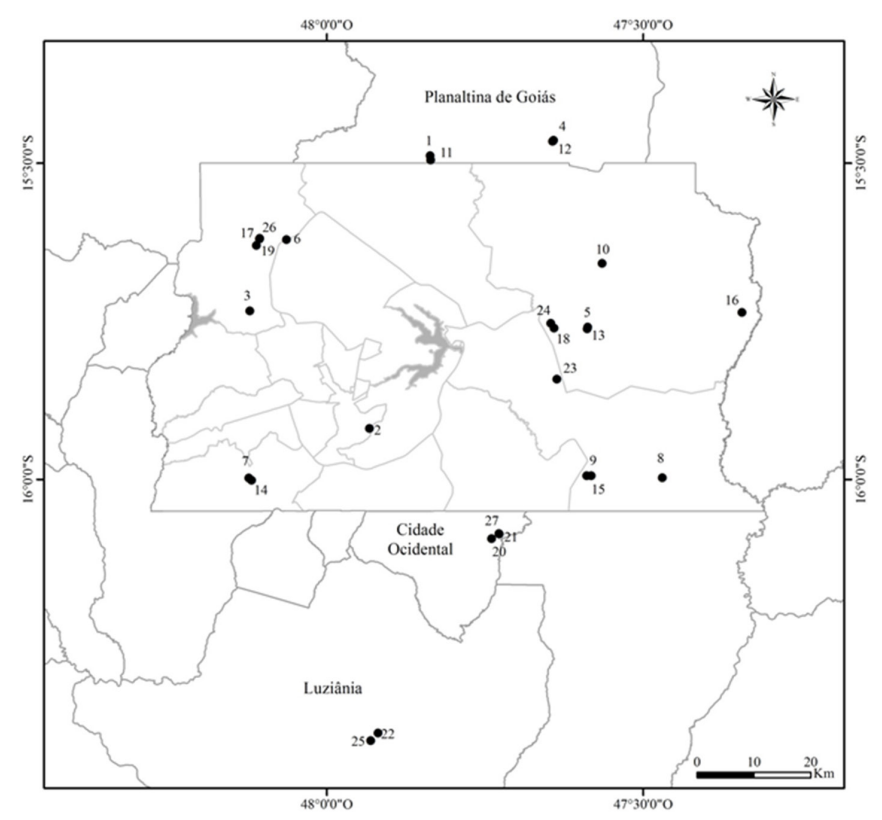

Figure 1. Location of the areas where the 27 participatory tests were placed at the agricultural regions of the Federal District. 
clones, generated and selected by the Embrapa Cerrados cassava breeding program (Clone 26/08, Clone 83/08, Clone 90/08, Clone 91/08, Clone 94/08, Clone 215/08, Clone 246/08, Clone 259/08, Clone 272/08 (BRS 396), Clone 273/08 (BRS 397), Clone 446/08 (BRS 398), Clone 497/08 (BRS 399) and Clone 450/08. The sweet cassava variety IAC 576-70 was used as control. This variety, known popularly in the Cerrado region as "Japonesinha", is identified at the Cerrado Cassava Germplasm Bank (BGMC) as BGMC 753. It is the most popular sweet cassava variety in the region. The participative tests lasted for three harvest seasons, 2011/2012, 2012/2013 and 2013/2014. Clones 90/08, 91/08 and 94/08 were evaluated only in the $2011 / 2012$ harvest because they had displayed, during $81 \%$ of the participatory tests, symptoms of Phytoplasma disease.

The farmers participating in the research were selected from different agricultural regions of the DF based on their availability, and experience with cassava cultivation. The plots consisted of 5 lines with 10 plants, 1.20 m between rows and $0.80 \mathrm{~m}$ between plants, and the plot area consisted of 24 central plants. The plants were cultivated following methods commonly applied by the producers selected for the participatory research; in this manner, the only difference in the producers' cultivation process was the cultivar.

Cassava roots were planted between October and December and harvested between 11 and 12 months after planting. At the time of harvest, the farmers classified the clones according to their preference for planting, considering the entire crop cycle and not only the yield. Thus, in each of the 27 selection environments, the clones were classified in a decreasing order of preference: the best clone (according to the producers) was placed in the first position and the worst in position 11 (Table 1). At that moment, the main criteria used by the producers for the selection of cassava clones were also noted. The growers, who know the local cassava market very well, preferred the clones with yellow pulp. Additionally, they paid especial attention to root cooking time (TC), which is directly associated with culinary quality, resistance to pests and diseases, initial vigor, which are associated with rapid soil cover and control of invasive plants, and uniformity of the root.

At harvest, the following characteristics were also ascertained: i) height of the first branching in $\mathrm{m}$ (HFB); ii) plant height in $\mathrm{m}$ (HP); iii) shoot weight without the original stem cutting in $\mathrm{kg} \mathrm{ha}^{-1}$ (ShW); iv) root weight in $\mathrm{kg} \mathrm{ha}^{-1}$ (RY); v) percentage of starch in the roots using the scale method; and vi) time for cooking the roots, in minutes (CT).

Based on the absolute probability of acceptance of the clones, cultivars BRS 396, BRS 397, BRS 398 and BRS 399 (Tables 1 and 2) won the first four positions. They were accepted with more enthusiasm than the most popular cassava cultivar in the DF, IAC 576-70, which was used as control variety in this work. In addition, i) BRS 399 had a $40.74 \%$ probability of being preferred, $77.78 \%$ probability of being classified until second place, $77.78 \%$ probability of being among the first three clones and $88.89 \%$ probability of being until the fourth; ii) BRS 397 had $14.81 \%$ probability of being preferred, $29.63 \%$ probability of being classified until second place, $59.26 \%$ probability of being among the first three

Table 1. Farmers' order of preference with respect to 14 clones of sweet cassava evaluated in 27 participatory tests at the Federal District

\begin{tabular}{|c|c|c|c|c|c|c|c|c|c|c|c|}
\hline \multirow{2}{*}{ Clones } & \multicolumn{11}{|c|}{ Preference order } \\
\hline & $1^{\circ}$ & $2^{\circ}$ & $3^{\circ}$ & $4^{\circ}$ & $5^{\circ}$ & $6^{\circ}$ & $7^{\circ}$ & $8^{\circ}$ & 9o & 109 & 110 \\
\hline BRS 399 & 11 & 10 & 0 & 3 & 2 & 0 & 1 & 0 & 0 & 0 & 0 \\
\hline BRS 397 & 4 & 4 & 8 & 5 & 4 & 2 & 0 & 0 & 0 & 0 & 0 \\
\hline BRS 396 & 3 & 4 & 12 & 6 & 2 & 0 & 0 & 0 & 0 & 0 & 0 \\
\hline BRS 398 & 4 & 4 & 2 & 4 & 4 & 6 & 2 & 1 & 0 & 0 & 0 \\
\hline IAC 576-70 & 1 & 2 & 4 & 4 & 6 & 6 & 2 & 2 & 0 & 0 & 0 \\
\hline $26 / 08$ & 0 & 0 & 0 & 0 & 1 & 0 & 0 & 10 & 1 & 4 & 11 \\
\hline $90 / 08$ & 0 & 0 & 0 & 0 & 0 & 0 & 0 & 0 & 0 & 5 & 5 \\
\hline 91/08 & 0 & 0 & 0 & 0 & 0 & 0 & 0 & 0 & 5 & 4 & 1 \\
\hline $94 / 08$ & 0 & 0 & 0 & 0 & 0 & 0 & 0 & 0 & 5 & 1 & 4 \\
\hline $83 / 08$ & 0 & 0 & 1 & 0 & 1 & 2 & 3 & 5 & 2 & 2 & 1 \\
\hline
\end{tabular}


Table 2. Accumulated probability of acceptance calculated for 14 sweet cassava clones evaluated in 27 participatory tests in the Federal District agricultural regions

\begin{tabular}{|c|c|c|c|c|c|c|c|c|c|c|c|}
\hline \multirow{2}{*}{ Clones } & \multicolumn{11}{|c|}{ Preference order } \\
\hline & $1^{\circ}$ & $2^{\circ}$ & $3^{\circ}$ & $4^{\circ}$ & $5^{\circ}$ & $6^{\circ}$ & $7^{\circ}$ & $8^{\circ}$ & 9o & 109 & 119 \\
\hline BRS 399 & 40.74 & 77.78 & 77.78 & 88.89 & 96.30 & 96.30 & 100.00 & 100.00 & 100.00 & 100.00 & 100.00 \\
\hline BRS 397 & 14.81 & 29.63 & 59.26 & 77.78 & 92.59 & 100.00 & 100.00 & 100.00 & 100.00 & 100.00 & 100.00 \\
\hline BRS 396 & 11.11 & 25.93 & 70.37 & 92.59 & 100.00 & 100.00 & 100.00 & 100.00 & 100.00 & 100.00 & 100.00 \\
\hline BRS 398 & 14.81 & 29.63 & 37.04 & 51.85 & 66.67 & 88.89 & 96.30 & 100.00 & 100.00 & 100.00 & 100.00 \\
\hline IAC 576-70 & 3.70 & 11.11 & 25.93 & 40.74 & 62.96 & 85.19 & 92.59 & 100.00 & 100.00 & 100.00 & 100.00 \\
\hline $26 / 08$ & 0.00 & 0.00 & 0.00 & 0.00 & 3.70 & 3.70 & 3.70 & 40.74 & 44.44 & 59.26 & 100.00 \\
\hline $90 / 08$ & 0.00 & 0.00 & 0.00 & 0.00 & 0.00 & 0.00 & 0.00 & 0.00 & 0.00 & 50.00 & 100.00 \\
\hline 91/08 & 0.00 & 0.00 & 0.00 & 0.00 & 0.00 & 0.00 & 0.00 & 0.00 & 50.00 & 90.00 & 100.00 \\
\hline $94 / 08$ & 0.00 & 0.00 & 0.00 & 0.00 & 0.00 & 0.00 & 0.00 & 0.00 & 50.00 & 60.00 & 100.00 \\
\hline $83 / 08$ & 0.00 & 0.00 & 5.88 & 5.88 & 11.76 & 23.53 & 41.18 & 70.59 & 82.35 & 94.12 & 100.00 \\
\hline
\end{tabular}

Table 3. Means of the traits evaluated: plant height in $\mathrm{m}(\mathrm{PH})$, height of first branching in $\mathrm{m}$ (HFB), root productivity in kg ha-1 $(\mathrm{PR})$, cooking time in $\min (\mathrm{TC}) ; \mathrm{HCN}$ amounts in ppm, evaluated in 14 sweet cassava clones evaluated in 27 participatory tests in the Federal District agricultural regions

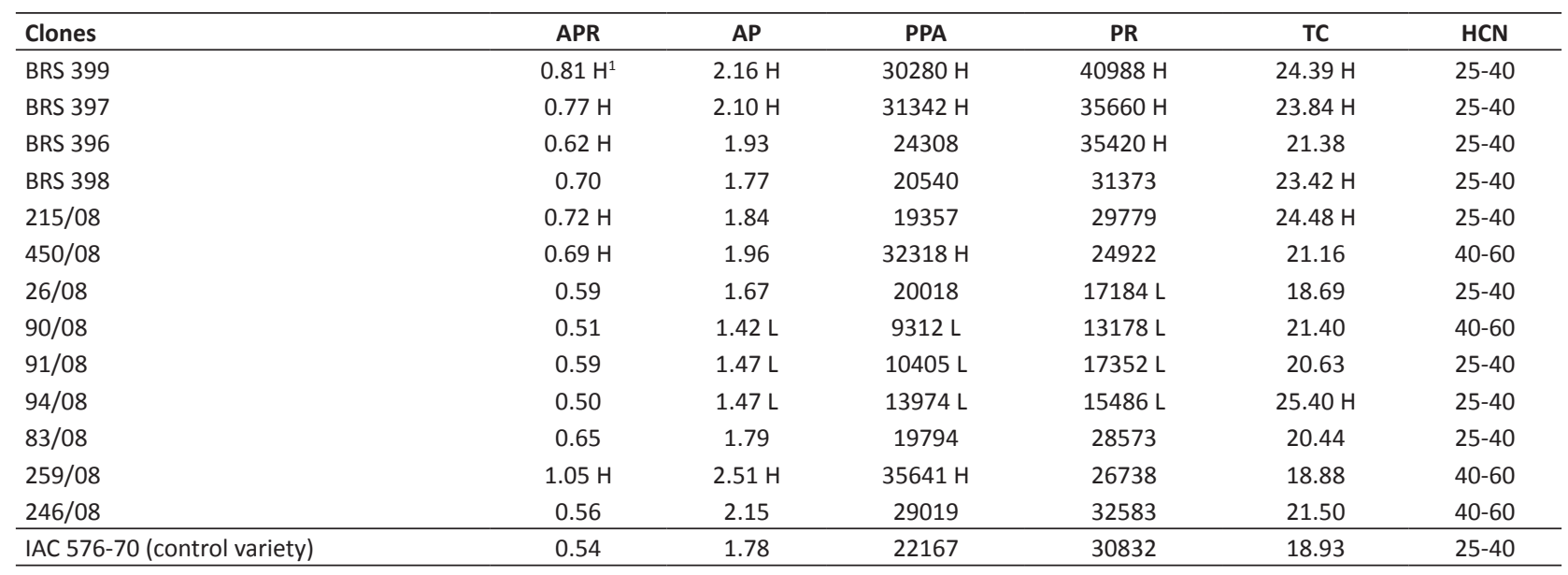

${ }^{1}$ Means followed by $\mathrm{H}$ or $\mathrm{L}$ are, respectively, higher or lower than the mean of the control variety (IAC 576-70) according to the $t$ test at $5 \%$ error probability.

clones and $77.78 \%$ probability of being until the fourth; iii) BRS 396 had a $11.11 \%$ probability of being preferred, $25.93 \%$ probability of being classified until second place, $70.37 \%$ probability of being among the first three clones and $92.59 \%$ probability of being until the fourth; and iv) BRS 398 had a $14.81 \%$ probability of being preferred, $29.63 \%$ probability of being classified until second place, $37.04 \%$ probability of being among the first three clones, and $51.85 \%$ probability of being until the fourth (Table 2).

The high acceptance of the cultivars by the producers is a direct reflection of their agronomic potential, since all of them cooked in less than 30 min, had HCN levels in roots below $100 \mathrm{mg} \mathrm{kg}^{-1}$ and for the other traits or were better than or equal to the control variety (Table 3).

The results obtained, together with the coloration of the root pulps, certainly qualify cultivars BRS 396, BRS 397 and BRS 399 (yellow pulp) and BRS 398 (cream pulp) as suitable for cultivation in the region of the Federal District and they may contribute to the increase of genetic variability in cultivation. 


\section{REGISTRATION, PROTECTION, BASIC PLANT AND LICENSING OF SEED MANUFACTURERS}

Cultivars BRS 396, BRS 397, BRS 398, BRS 399 are registered and protected by Ministério de Agricultura, Pecuária e Abastecimento (MAPA), under numbers 33078 and 20150160, 33073 and 20150169, 33074 and 20150123 and 33076 e 20150162, respectively.

The basic plant production and the licensing of seed producers are under the responsibility of Secretaria de Inovação e Negócios da Embrapa - SIN, Parque Estação Biológica - PqEB, Av. W3 norte (final), S/N, Ed. Embrapa Sede, 1ㅇandar, 77.770-901, Brasília, DF.

\section{ACKNOWLEDGEMTS}

We thank Empresa Brasileira de Pesquisa Agropecuária (Embrapa), à Fundação Banco do Brasil (FBB) and Conselho Nacional de Desenvolvimento Científico e Tecnológico (CNPq), for financial support and EMATER-DF for general help.

\section{REFERENCES}

Carvalho LJCB, Vieira EA, Fialho JF and Souza CRB (2011) A genomic assisted breeding program for cassava to improve nutritional quality and Industrial traits of storage root. Crop Breeding and Applied Biotechnology 11: 289-296.

Chiorato AF, Carbonell SAM, Gonçalves JGR, Silva DA, Benchimol-Reis LL, Carvalho CRL, Barros VLNP, Freitas RS, Ticellis M, Gallo PB and Santos NCB (2018) IAC Sintonia: new carioca common bean cultivar. Crop Breeding and Applied Biotechnology 18: 338-342.

Franco FA, Marchioro VS, Evangelista A, Polo M, Montecelli TDN, Souza LV, Schuster I, Lima FJA, Santos DA and Grave EL (2018) CD 1705 healthy and high-yielding wheat cultivar for biscuit manufacturing. Crop Breeding and Applied Biotechnology 18: 334-337.

Fialho JF and Vieira EA (2011) Seleção participativa de variedades de mandioca na agricultura familiar. Embrapa Cerrados, Brasília, 76p.

Fialho JF, Sousa DMG and Vieira EA (2013) Manejo do solo no cultivo de mandioca. In Fialho JF and Vieira EA (eds) Mandioca no Cerrado: orientações técnicas. Embrapa Cerrados, Brasília, p. 39-60.

Fialho JF and Vieira EA (2013) Manejo e tratos culturais da mandioca. In Fialho JF and Vieira EA (eds) Mandioca no Cerrado: orientações técnicas. Embrapa Cerrados, Brasília, p. 61-88.

Vieira EA, Fialho JF, Faleiro FG, Bellon G, Fonseca KG, Carvalho LJCB, Silva MS, Paula-Moraes, SV, Oliveira CM and Denke ML (2011a) Characterization of sweet cassava accessions based on molecular, quantitative and qualitative data. Crop Breeding and Applied Biotechnology 11: 232-240.

Vieira EA, Fialho JF, Silva MS, Paula-Moraes SV, Oliveira CM, Anjos JRN, Rinaldi MM, Fernandes FD and Guimarães Junior R (2011b) BRS Japonesa: new sweet cassava cultivar for the Distrito Federal region. Crop Breeding and Applied Biotechnology 11: 93-196.

Williams HJ and Edwards TG (1980) Estimation of cyanide with alkaline picrate. Journal of the Science of Food and Agriculture 31: 15-22.

(cc) EY This is an Open Access article distributed under the terms of the Creative Commons Attribution License, which permits unrestricted use, distribution, and reproduction in any medium, provided the original work is properly cited. 